\title{
The Influence of Pull-Up and Push-Up Training on 50-Meter Chest Switch Speed
}

\author{
Dwi Prasetyo Pambudi, Herita Warni, AR. Shadiqin \\ Department of Sport Education and Health \\ Lambung Mangkurat University \\ Banjarmasin, Indonesia \\ dwiprasetyopambudi88@yahoo.co.id
}

\begin{abstract}
This study aims to determine the effect of pull up and push up exercises on the 50 meter breaststroke swimming speed of the STIKIP Paris Berantai student at Kotabaru Regency. The research method used is the pre-experiment design method. The population in this study were the STIKIP Paris Chain students who took swimming courses after being verified that there were populations that met the criteria of 30 people. While the sample of this research is 20 people. The sampling technique uses simple random sampling. The results showed that: 1) there was an effect of pull up training on the $50 \mathrm{~m}$ breaststroke swimming speed of the STIKIP Paris Berantai student at Kotabaru Regency; 2) there is an effect of push up training on the $\mathbf{5 0}$ meter breaststroke swimming speed on the STIKIP Paris Berantai District Kotabaru students; and 3) there is a difference in the effect of pull up and push up exercises on the $50 \mathrm{~m}$ breaststroke swimming speed of the STIKIP Paris Berantai student at Kotabaru Regency.
\end{abstract}

Keywords: exercise, pull-up, push-up, swimming

\section{INTRODUCTION}

Chest-style swimming movements are basically more focused on the movements of the hands and feet, but there are also supporting movements, namely movements on the neck or head. The dominant motion in breaststroke swimming is the hands and feet, it is necessary to improve the ability of the stroke of the arms so that the swimming speed of the breaststroke is more optimal. Pull up exercises have a significant influence on the ability of the breaststroke swimming arm stroke in State Vocational School students 2 times [1]. Observations on September 22, 2015 only 20 out of 30 students who took swimming courses were able to do breaststroke swimming with the correct technique. Although the technique of swimming is correct (basic movements of the foot, breathing, glide and arms), the speed is still relatively poor with an average travel time of 01 minutes 25 seconds for a distance of 50 meters. Possible causes of the lack of swimming ability are weak arm and shoulder muscles and the use of breathing techniques that are not optimal when swimming. Thus supporting the ability to swim 50 meters breaststroke and the utilization of their arm and shoulder muscle groups still needs to be revealed.

The ability to improve the quality of basic biomotor (strength, endurance, speed, flexibility and coordination) is greatly affected by the role of a trainer, if the trainer does not have a training background then it will be difficult to improve the quality of the basic biomotor. This condition results in an exercise program to improve the quality of the muscles of the arms and shoulders that has never been planned. Periodization of exercises to increase biomotor, especially strength, speed and endurance [2]. A good trainer qualification should have attended trainer training for example at the regional or national level. Therefore the application of the training method so far is still unclear, such as training programs to increase the strength of the arm and shoulder muscles are still not directed and are not well targeted, so the ability to swim or swim speed of students who are fostered is still far from expectations. Setting "training principles and establishing training components such as intensity, volume, frequency and repetition" exercises must always be in accordance with the objectives of the exercise [2].

As is well known that when a person learns to swim is always taught skating techniques, either with the help of the push of both legs or pedaling both arms. If the forward force caused by foot repulsion has ended, then the sliding motion in the breaststroke swimming is influenced by the pulling force of both arms. The coordination of leg movements and pulling strength by both arms when swimming is very dominant resulting in forward movement speed. Thus to gain arm and shoulder muscle strength, among others it can be done with pull up and push up exercises. Because the strength of the arm and shoulder muscles are interconnected and have a dominant role in breaststroke swimming, its effects on changes in swimming speed need to be revealed immediately. This is important because the type of pull up and push up exercises are easy to do by anyone and the availability of ingredients does not require expensive equipment, but the benefits are very important to affect swimming speed [1].

As a solution to answer the problem, the effect of pullup and push-up exercises on the swimming speed of the breaststroke 50 meters needs to be immediately assessed through an experimental study. The general objective is to determine and compare the effect of two forms of treatment on the dependent variable, namely swimming speed of 50 meters breaststroke. Sample criteria to be used are students who truly have mastered the basic techniques of breaststroke swimming and are able to swim within 200 meters without a break or have passed swimming courses at the STIKIP Paris Berantai Kota Baru. This is determined so that the effect of the treatment becomes clear the difference between speed and ability to swim with a constant wave force technique that is the breaststroke from the cue from start to finish along the 50 meters. 


\section{METHOD}

The The method used in this study was pre-experimental. Pre-experiment is quasi-experimental research, or there are still external variables that influence the formation of the dependent variable [3]. So this can happen, because there are no control variables, and the sample is not chosen randomly. The design in this study uses One-Group Pretest-Posttest Design, which means that before being treated there is a pretest, and after the treatment is given a post-test [3]. The population in this study were the STIKIP Paris Chain students who took swimming courses after being verified that there were populations that met the criteria of 30 people. While the sample of this research is 20 people.

\section{RESULTS AND DISCUSSION}

Arm muscle strength training uses pull-up and push-up exercises to increase the swimming speed of the breaststroke, with exercise intensity between 75 - 85\% of maximum strength. The maximum strength phase of the training time ranges from 1 to 3 months, the training set is recommended from 2 to 3 sets with 4 to $6 \mathrm{RM}$, while the training load is between 75 to $85 \%$ of maximum strength [4].

Doing pull-up and push-up exercises for 6 weeks or 18 meetings with a frequency of 3 times a week held in the Kota Baru Swimming Pool for students who take classes in swimming courses. The application of arm strength training exercises the weight of the exercise between 75 to $85 \%$ of maximum strength, so that the muscles can adapt, the exercise is carried out for 6 weeks. with these exercises an increase in arm muscle strength will occur. By having better arm muscle strength, the swimming speed of the breaststroke will increase, this strength of the arm muscle greatly affects the stroke of the arm when doing breaststroke swimming.

Based on the results of hypothesis testing using the t-test or t test as follows:

A. The Effect of Pull-up Exercises on the 50 meter Breaststroke swimming Speed of the STIKIP Paris Berantai District Kotabaru Students.

The results of the analysis of the pretest variable t test with a 50 meter breaststroke swimming speed test for STIKIP Paris Berantai District Kotabaru students in the pull-up training group, obtained tcount $=8.937>$ ttable $(9$; $0.025)=2.262$, or with Sig. $(2$-tailed $)=0,000$; it turns out that Sig. (2-tailed) $=0,000<0.05$ thus the tcount is significant. So it can be concluded that there is or there is an influence by using pull-up exercises to the speed of the breaststroke swimming 50 meters in STIKIP Paris Berantai students of Kotabaru Regency.

Pull-up exercises in this study increased the swimming speed of the breaststroke 50 meters in the STIKIP Paris Berantai District Kotabaru students. Pull up exercises can increase strength according to the theory put forward that pull ups are exercises to strengthen elbow flexors, shoulder extensor joints, scapular adductors and rotators downward [5]. So pull up exercises conducted for 6 weeks or 18 meetings with a frequency of 3 times a week can increase strength, by having good strength, it will affect the stroke in doing breaststroke swimming. This research proves that the pull up exercise has an influence on the 50 meter breaststroke swimming speed for STIKIP Paris Berantai students in Kotabaru Regency.

The results of this study indicate that there is an influence of pull up training on the 50 meter breaststroke swimming speed of STIKIP Paris Berantai students in Kotabaru Regency. In line with the results of research under the influence of pull-up and dumble biceps curl exercises on the ability of the breaststroke swimming arm stroke [1]. The results of this study indicate that there is or is the effect of pull-up exercises on the ability of the breaststroke swimming arm stroke.

B. The Effect of Push-up Exercises on the 50-meter Breaststroke Swimming Speed of the STIKIP Paris Berantai District Kotabaru Students.

The results of the analysis of the $t$ test (paired t-test) pretest variable with posttest breaststroke swimming speed (breaststroke) 50 meters in STIKIP Paris students in the Kotabaru District Push-up exercise group, obtained tcount $=$ 5.338 $>$ ttable $(9 ; 0.025)=2.262$, where Sig. $(2$-tailed $)=$ 0,000 ; it turns out that Sig. (2-tailed) $=0,000<0.05$ thus the tcount is significant. So that conclusions can be drawn that there is an effect of push-up exercises on the 50-meter breaststroke swimming speed at STIKIP Paris Berantai students.

Push-up exercises in this study increased the swimming speed of the breaststroke 50 meters in the STIKIP Paris Berantai student in the Kotabaru Regency. Push up exercises can increase strength according to the theory put forward that push ups are exercises to strengthen the elbow extensors and shoulder and chest anterior muscles [5]. Then push up exercises conducted for 6 weeks or 18 meetings with a frequency of 3 times a week can increase strength, by having good strength, it will affect the stroke in doing breaststroke swimming. This research proves that the pushup exercise has an influence on the 50-meter chest-style swimming speed (breasstroke) of the STIKIP Paris Berantai student at Kotabaru Regency.

The results of this study indicate the influence of pushup training on the 50-meter breaststroke swimming speed of the STIKIP Paris Berantai student. This study is in accordance with the results of a study under the title of the influence of push-up training on increasing the strength of pulling and pushing arm muscles [6]. In that study there was an influence of push-up training on increasing the strength of pulling and pushing arm muscles.

\section{Effect of Pull-up and Push-up Exercises on the 50-meter Breaststroke Swimming Speed of the STIKIP Paris Chain students.}

The results of the t test (paired t-test) posttest variable pull-up group with posttest push-up group swimming speed 50 meter breaststroke in STIKIP Paris Berantai District Kotabaru students, obtained thitung $=2,820>$ ttable $(9$; $0.025)=2,262$, where Sig. (2-tailed) $=0,000$; it turns out that Sig. (2-tailed) $=0.020<0.05$ thus the tcount is significant. So it can be concluded that there is a difference in the effect of pull-up and push-up exercises on the $50 \mathrm{~m}$ 


\section{CONCLUSION}

breaststroke swimming speed of the STIKIP Paris Berantai student at Kotabaru Regency.

Pull up and push up exercises in this study increased the swimming speed of the breaststroke 50 meters in the STIKIP Paris Berantai District Kotabaru students. Pull up and push up exercises can increase strength according to the theory put forward that (1) push ups are exercises to strengthen the elbow extensors and shoulder and chest anterior muscles; (2) pull ups are exercises to strengthen elbow flexors, shoulder extensor joints, scapular adductors and downward rotators [5]. Then push up exercises conducted for 6 weeks or 18 meetings with a frequency of 3 times a week and using exercise intensity between $75-85 \%$ of maximum strength can increase strength. Strenght phase Maximum length of time for training ranges from 1 to 3 months, jumlat sets are recommended 2-3 sets with 4-6 RM, while the training load is between $75-85 \%$ of maximum strength (1RM) [4]. By having good strength, it will affect the stroke in doing breaststroke swimming. This research proves that the pull up and push up exercises have an influence on the 50 meter breaststroke swimming speed of the STIKIP Paris Berantai student at Kotabaru Regency.

The results of this study indicate that there is an influence of pull up and push up exercises on the swimming speed of the $50 \mathrm{~m}$ breaststroke in STIKIP Paris Berantai student at Kotabaru Regency. This study is in line with the results of research entitled the effect of pull-up and dumble biceps curl exercises on the ability of the breaststroke swimming arm stroke [1]. The results of this study indicate that there is an influence of pull-up exercises on the ability of the breaststroke swimming arm stroke. This study is also in line with the results of research entitled the effect of push-up training on increasing the strength of pulling and pushing arm muscles [6]. The results of this study indicate that there is an influence of push-up training on increasing the strength of pulling and pushing arm muscles.
The conclusions based on the results of this study are based on data analysis, hypothesis testing and discussion, that: 1) There is an influence of pull-up training on the speed of the 50-meter breaststroke swimming in STIKIP Paris Berantai students. 2) There is an influence of push-up training on the speed of the 50-meter breaststroke swimming in STIKIP Paris Berantai students. 3) There is a difference in the effect of pull-up and push-up exercises on the speed in the 50-meter breaststroke swimming at STIKIP Paris Berantai students.

\section{ACKNOWLEDGMENT}

We would like to be grateful to the Dean of Teacher Training and Education Faculty, Lambung Mangkurat University, who has supported us in the form of funding. Therefore we could join this International Conference.

\section{REFERENCES}

[1] Y. Arismunandar, S. Husin, and R. Hermawan, "Pengaruh Latihan Pull Up Dan Dumblebicepscurl Terhadap Kemampuan Kayuhan Lengan Renang Gaya Dada,” JUPE (Jurnal Penjaskesrek), vol. 1, no. 2, 2013.

[2] T. O. Bompa and C. Buzzichelli, "Periodization-: theory and methodology of training," Hum. Kinet., 2018.

[3] Sugiyono, Metode Penelitian Kombinasi (Mixed Methods), Bandung: Alfabeta, 2014

[4] J. Lubis, Panduan Praktis Penyusunan Program Latihan. Jakarta: PT Raja Grafindo Persada, 2013.

[5] K. Luttgens and K. Wells, Kinesiology: Scientific Basis of Human Motion, Philadelphia: Saunders, 1982.

[6] G. Aryana, "Pengaruh Pelatihan Push-Up Terhadap Peningkatan Kekuatan Menarik Dan Mendorong Otot Lengan," J. Ilmu Keolahragaan Undiksha, vol. 1, no. 1, 2013. 